\title{
Rolf Strootman, Miguel John Versluys (eds.), Persianism in Antiquity (Oriens et Occidens, Bd. 25), Franz Steiner Verlag, Stuttgart 2017, ill. b/w, pp. 557, ISBN 978-3-515-11382-3
}

There is a long history of fascination with the history of the Achaemenid Empire and its legacy in civilisation. This first surfaced shortly after the empire's decline, and has lasted with varying intensity until today. In recent decades, apart from issues concerning its history, scholars have also paid close attention to questions of the impact of the empire's tradition, both on its neighbours at the time and on later generations. This phenomenon is often referred to as Persianism. Between 1987 and 1997, the Achaemenid History Workshops series took place, one of its initiators being Heleen W. A. M. Sancisi-Weerdenberg. The cycle presented a broad range of the first analyses of the extent and way the tradition of Achaemenid Iran influenced the administrative and social structures of the states that rose from its ashes, as well as the place of these traditions in relations between Iran and the surrounding world. The meetings, attended by several dozen researchers in total, explored the diverse and long-term manifestations of this impact along with their huge persistence, as well as the wide use of these traditions by the Achaemenids' successors. Owing to the scale of this phenomenon, for several years, various aspects of Persianism have been the subject of intensive study. An attempt to sum these up was made by the colloquium Persianism in Antiquity, organised in Istanbul in 2014 by Rolf Strootman and Miguel John Versluys and dedicated to the cultural and political memory of the Iran of the Achaemenids in ancient times. The papers presented at the conference, attended by several dozen scholars from various countries, have now been published. These proceedings also contain a series of texts that were not presented there. In total, the volume contains 21 articles, all but one of them written in English.

The texts in the book are divided into three groups: I. Persianization, Persomania, Persererie; II. The Hellenistic World; III. Roman and Sasanian Perspectives. The volume opens with an interesting and methodologically important article by the colloquium's two organisers and editors (R. Strootman, M. J. Versluys, The Reception and Appropriation of Persia in Antiquity, pp. 9-32). This proposes definitions of various phenomena associated with the historical memory of the Achaemenids, which are generally known as Persianism. The authors identify three main forms of these phenomena. They suggest reserving the concept of Persianism for "the ideas and associations revolving around Persia and appropriated in specific contexts for specific (socio-cultural or political) reasons" (p. 9). They treat it as a conventional, catch-all phrase, and at the same time convenient to use, as it can describe various manifestations of historical memory of the Achaemenids (pp. 9-10). ${ }^{1}$

${ }^{1} \mathrm{Cf}$. "The concept of Persianism thus allows us to study the genesis of the 'Idea of Persia/Iran' in both Iranian and non-Iranian historical contexts" (p. 11). 
The authors propose using the term "Persianisation" for phenomena related to the direct influence of Achaemenid Iran on its contemporary neighbours (p. 10), and referring to everything connected to the idea of Iran (Ërānšahr or Ērān), which emerged in the period of Sasanid rule, as "Iranism" (pp. 10-11). The need to introduce these concepts into universal usage seems entirely justified. This is not least because we can use them to better describe and classify various manifestations of historical, social, cultural, religious and ideological phenomena associated with the operation of Achaemenid traditions in the ancient world.

The six articles in the first part of the book are somewhat different from those in the other two. They contain articles that refer to issues that go beyond the framework of Persianism in the way that the book's authors understand it. The problems they analyse are connected, however, more or less loosely. Their authors attempt to identify criteria that were an element of the identity of the ancient Persians in various periods and various places in the ancient world (A. de Jong, Being Iranian in Antiquity (at Home and Abroad), pp. 35-47), cite arguments for the presence of Persian inspirations in Athens in both the private and the public spheres and their sources (M.C. Miller, Quoting 'Persia' in Athens, pp. 49-67), describe how the Persians were perceived and judged in Greek art (L. Llewellyn-Jones, 'Open Sesame!' Orientalist Fantasy and the Persian Court in Greek Art 430-330 BCE, pp. 69-86) and signs of memory of the Achaemenids in the early modern period. Articles on modern times also cover the issue of the picture of memory of the Achaemenids in societies living close to monuments exploiting this memory for political and ideological purposes (J. A. Lerner, Ancient Persianisms in Nineteenth-Century: The Revival of Persepolitan Imagery under the Qajars, pp. 107-119), recreated on the basis of accounts of European travellers (O. Coloru, Once Were Persians: The Perception of Pre-Islamic Monuments in Iran from the $16^{\text {th }}$ to $19^{\text {th }}$ Century, pp. 87-106), as well as the question of the place of the Achaemenids in the history of the ancient world in Oswald Spendler's conception of the philosophy of history (D. Engels, Is there a 'Persian High Culture?' Critical Reflections on the Place of Ancient Iran in Oswald Spengler's Philosophy of History, pp. 121-144).

The section about the phenomenon of Persianisation in the Hellenistic world contains seven articles (D. Agut-Labordère, Persianism through Persianization: The Case of Ptolemaic Egypt, pp. 147-162; S. Plischke, Persianism under the early Seleucid Kings? The Royal Title 'Great King', pp. 163-176; R. Strootman, Imperial Persianism: Seleukids, Arsakids and Fratarakā, pp. 177-200; M. Canepa, Rival Images of Iranian Kingship and Persian Identity in Post-Achaemenid Western Asia, pp. 201-222; C. LerougeCohen, Persianism in the Kingdom of Pontic Kappadokia. The Genealogical Claims of the Mithridatids, pp. 223-233; B. Jacobs, Tradition oder Fiktion? Die 'persischen' Elemente in den Ausstattungsprogrammen Antiochos' I. von Kommagene, pp. 235-248; B. Eckhardt, Memories of Persian Rule: Constructing History and Ideology in Hasmonean Judea, pp. 249-265). Using various types of local sources, their authors strive to show how the memory of the Achaemenids worked in different areas of their former state, how it was manifested, the purposes for which it was nurtured and exploited, and how, over the course of time, the attitude towards this memory changed among those who, for whatever reason, invoked the Achaemenids. 
Each article contains a description of cases in which the memory of the Achaemenids was used for propaganda purposes and to achieve political aims, not only by the Seleucids or Ptolemies, but mostly by local dynasts. These demonstrate that their references to dynastic links with the Achaemenids, use of Persian iconography and religious traditions were very often exploited to legitimise their rule. The fact that memory of the Achaemenids remained alive in the great Hellenistic monarchies comes as no great surprise, since Alexander the Great's conquest of the empire that they founded was part of the propaganda of the Macedonian leaders who formed their own dynasties after his death. What is notable is the numerous cases of the local dynasts invoking the Achaemenid memory in their efforts for political independence, mainly in relation to the Seleucids.

There are also seven articles in the final part of the volume, which concentrates on the phenomenon of Persianism in the period of Roman domination in the East and during the rule of the Sasanid dynasty. Four of these refer to the former period, and the other three to the latter. The authors of the articles on Persianism in the Roman period present extremely interesting examples of how the memory of the Achaemenids and the related traditions functioned at the time. One of these is described in V. Sergueenkov and F. Rojas's article Persia on their Minds: Achaemenid Memory Horizons in Roman Anatolia (pp. 269-288). The authors sketch the religious practices of Persian provenance that took place in various cities in Western Anatolia during the Empire. They regard these as a manifestation of local tradition, with roots stretching back to the time of Achaemenids, but by no means anti-Roman in nature. According to the others, it was even in the Roman interest to nurture it. ${ }^{2}$ The matter of the Iranian lineage of the cult of Mithra and the descriptions of it surviving in the writings of Roman authors is analysed by R. Gordon (Persae in spelaeis Solem colunt: Mithra(s) between Persia and Rome, pp. 289-325). He argues that, by using the concept of Persianism in the discussion on Mithraism, one gains a much better understanding of the phenomenon of this religion on Roman territory, which goes beyond the limits of perceiving it from the perspective of exclusively Iranian or Roman traditions. E. Almagor (The Empire Brought Back: Persianism in Imperial Greek Literature, pp. 327-343), who has long been interested in the picture of Persia painted in Plutarch's works, attempts to show how the Achaemenids were depicted in the works of Greek authors of the imperial era. This was the time when they began to demonstrate a particularly great interest in the history of the Persian Empire. The author finds an array of reasons for this. These include the war of Rome with the Parthians, but also as an indication of nostalgia for lost independence, which made it possible to enjoy success in the struggle against a powerful empire. By recalling a distant and glorious past, at the same time they were able to make a veiled critique of the reality in which they lived.

Ammianus Marcellinus' account contains many references to the history of the Achaemenids which are popular among scholars of the history of ancient Iran, who regard him as an extremely reliable historian. M. Sommer's article (The Eternal Persian: Persianism in Ammianus Marcellinus, pp. 345-354) is an attempt to assess their value and credibility. Sommer's view differs from the common approach, as he maintains that

2 “...from a Roman perspective, local pride in Achaemenid royal precedents had a validating effect: it confirmed the legitimacy of Roman imperial power in line that went from Semiramis to Cyrus and Alexander to Augustus" (p. 288). 
all the Roman historian's statements concerning the history of the Achaemenids, Parthians, and even Sasanids should be treated with caution. He justifies this conclusion by noting that Ammianus Marcellinus treated the Sasanid state from his own time as a continuation of the Achaemenid Empire (pp. 349-353). The picture he paints of Iran's past is therefore static, anachronistic and ahistorical. ${ }^{3}$

R. Fowler offers a similar view of Josephus' Persianism (Cyrus to Arsakes, Ezra to Izates: Parthia and Persianism in Josephus, pp. 355-379), but from the angle of his assessment of the Arsacids, as the Jewish historian wrote little about the Achaemenids themselves. Given the hopes that the Jews placed in the Parthians that their support would help bring them independence in the context of the Arsacids' wars with Rome, one might expect this assessment to be extremely positive. Yet the opinions that Josephus expressed on the Parthians in fact suggest that he was very much ambivalent towards them. Certainly among the reasons for this was his close relationship with the Romans, which ruled out praising their rival, but also there was the ambiguous behaviour of the Parthians themselves towards the Jews, of which numerous examples can be found on the pages of Antiquitates. It is also notable that one cannot always determine Josephus' attitude to the events from the time of the Achaemenids which he mentions in the context of Jewish-Parthian relations, or even what their objective is. ${ }^{4}$ The next two articles should be read together, as their authors both reflect upon the issue of the concept of the (holy) land of Iran (Ërānšahr) in the ideology and religion of the Sasanids (J. Wiesehöfer, Ėrān and Anērān: Sassanian Patterns of Worldview, pp. 381-391; T. Daryaee, The Idea of the Sacred Land of Ėrānšahr, pp. 393-399). Both authors conclude that, while certain elements of this idea were framed even in the Achaemenid period, by no means did the Sasanids refer to them directly. In the ideological sphere, by passing over the name of the Achaemenids, the Sasanids were able to invoke the tradition of the Kayanids, and in the religious sphere to Avesta. The last article in the volume is M. R. Shayegan's Persianism: or Achaemenid Reminiscences in the Iranian and Iranicate World(s) of Antiquity (pp. 401-455), an extensive overview of the forms of reference to memory of the Achaemenid memory in antiquity. A number of long passages from it refer to those figures of Persianism also presented by other authors.

All of the texts published in this volume contain worthwhile findings and observations that add greatly to our knowledge of how memory of the Achaemenids functioned over the centuries among the states that had been in borders of theirs empire, what form it had and how it was used. The wealth of examples the book analyses mean that it will certainly be of interest to all scholars who have dealt with the issues of Persianism in the past, or will do so in future. There is no doubt that the concept of Persianism as proposed by R. Strootman and M. J. Versluys opens research perspectives that are both new and interesting.

Edward Dąbrowa (Jagiellonian University in Kraków)

3 “...it is remarkable how profoundly ahistoric this historian's narrative is. In the entire digression about Persia, there is no visible awareness of historical development, diachronic rupture or structural patterns that may or may not be genetically related to each other. To Ammianus, the 'Persians' are simply the 'Persians', once and for all. Their portrayal is. Hardly surprisingly, saturated with prejudice and stereotype. There is no evidence for any attempt to overcome, deconstruct or replace such established patterns" (p. 353).

4 "What is unclear in each instance (and perhaps unanswerable) is whether Josephus's account reflects the Parthians' own 'Persianism', or whether he is himself 'Persianising' the Parthians” (pp. 378-379) 